\title{
ECONOMIC DEVELOPMENT IN THE SLOVAK REPUBLIC: ACHIEVED RESULTS AND PROSPECTS FOR FUTURE DEVELOPMENT
}

\author{
Dudić Branislav ${ }^{1}$, \\ Beňová Eleonóra ${ }^{2}$, \\ Mirković Vladimir ${ }^{3}$, \\ Dudić Zdenka .
}

\begin{abstract}
Slovakia's accession to the EU provided a positive impulse for further economic development, describing the main indicators of the business environment, including the analysis of the general macroeconomic environment, GDP and the labor market. The Slovak Republic focuses on current trends regarding the issue of shortages of skilled labor and employment of foreigners. The most important tasks that the Slovak Government must provide in Slovakia are sustainable economic growth combined with job creation and improving business conditions. Foreign direct investment and corporate sector are major factors that will initiate growth of the economy and employment in Slovakia. New investments also mean modernization of production, new technologies, creating new jobs and progress of the economy. This paper puts a special emphasis on the benefits of the fourth
\end{abstract}

\footnotetext{
${ }^{1}$ University Business Academy, Faculty of Economics and Engineering Management, Cvećarska 2, 21000 Novi Sad, Republic of Serbia, e-mail:

branislav.dudic@fimek.edu.rs; and Comenius University, Faculty of Management, Odbojárov 10, 82005 Bratislava, Slovakia.

${ }^{2}$ Comenius University Faculty of Management, Bratislava, Odbojárov 10, 82005 Bratislava, Slovak Republic, e-mail: jan.smolen@fm.uniba.sk

${ }^{3}$ National Bank of Serbia, Nemanjina 17, 11000 Beograd, Republic of Serbia, e-mail: vladamirkovic@orion.rs

${ }^{4}$ University Business Academy, Faculty of Economics and Engineering Management, Cvećarska 2, 21000 Novi Sad, Republic of Serbia, e-mail: zdenkadudic79@gmail.com
} 
industrial revolution, impersonated in the automation and digitalization of processes and continuous innovations, which resulted in the economic growth and development in Slovak Republic.

Key words: economic growth / business environment / GDP / investments / employment / Slovak Republic/

\section{INTRODUCTION}

In 2019 Slovak Republic has experienced record economic growth, which is the result of reform measures from previous years, as well as a favorable development of the global economy, thanks to which investors are looking for other opportunities to invest in Slovakia. The functions of the Slovak economic growth confirm that the acceleration of GDP creation was mainly due to an increase in the production capacity of the economy, especially in sectors with inflows of foreign direct investment.

Analysis of macroeconomic indicators of Slovak Republic can be divided into the analyses of:

- Gross domestic product

- Unemployment

- Inflation

- Foreign Trade

Gross domestic product represents the market value of all final goods and services produced in the country. Gross domestic product is the most comprehensive measure of the overall level of production of goods and services in a country. GDP includes all final goods and services produced by the economy and legally sold on the market.

\section{GROSS DOMESTIC PRODUCT}

Figure 1: Slovakia - Growth rate of the real gross domestic product (GDP) from 2014 to 2024 (compared to the previous year)

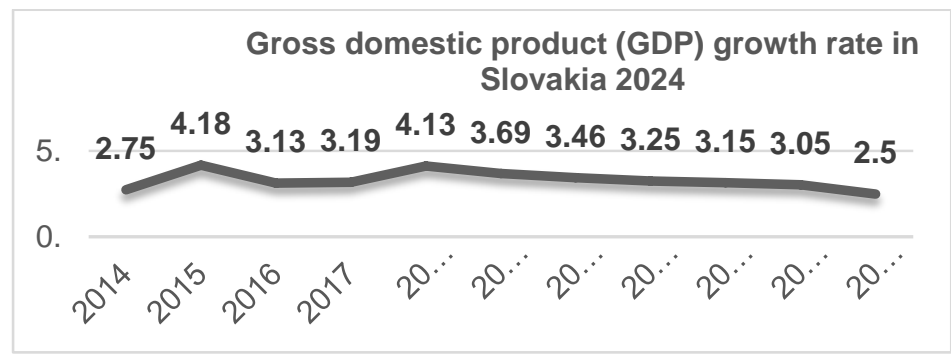

Source: Statista - The Statistics Portal (2019) 
The data presented in Figure 1 show the growth in real GDP in Slovakia from 2014 to 2017, with projections for the period until 2024. In 2017, Slovakia's real gross domestic product grew by around 3.19 percent compared to the previous year.

Economic growth at constant prices slowed to $3.6 \%$ in the fourth quarter of 2018, which also affected employment development; adjusted for seasonal effects, GDP increased by $0.8 \%$ in the fourth quarter of 2018 compared to the previous quarter, which is slightly weaker than forecasted. GDP at constant prices for 2018 increased by 4.1\%. The GDP development of the Slovak Republic in the period under review can be seen in Figure 2.

Figure 2: GDP growth at constant prices

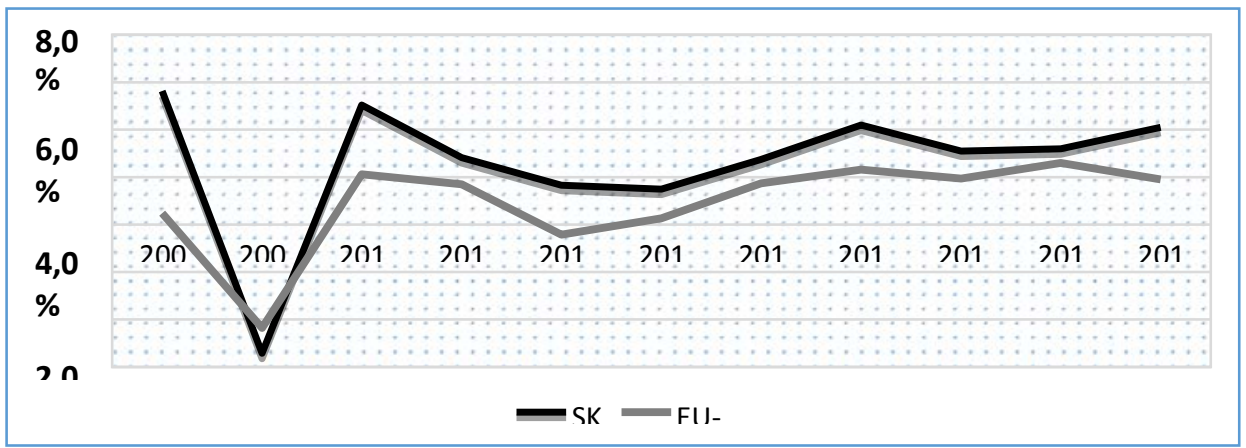

Source: World Bank (2019), Statistical Office of the Slovak Republic (2019), Eurostat (2019)

The main source of growth came from consumer demand. The positive economic development in Q4 2018 was mainly due to domestic demand growth of $5.8 \%$.

The European Commission (EC) predicts that Slovakia will be the third fastest growing euro area economy in 2019 and 2020. According to EC estimates, the improvement will be mainly due to an increase in real wages, further increases in employment and increased private consumption. In particular, the expansion of export capacity in the automotive sector can support economic activity. 
However, for continuous growth in this sector, the first and foremost necessity is to create better conditions for the automotive industry. In terms of sustainability and competitiveness of the automotive industry (as a key industry in Slovakia), it is very important to capture current trends. Some of them, such as the electric cars industry can represent potential threats for the Slovak economy (Smolen, 2016). A predictable positive development could come in the form of possible legislative changes affecting the business environment. The economic development of Slovakia, as a country with a strongly open economy and a high involvement in global value chains, will be affected by global economic developments, especially in the EU and the euro area, the USA and China, as well as other factors (e.g. Brexit).

\section{UNEMPLOYMENT AND LABOR MARKET DEVELOPMENT}

In 2018, favorable labor market developments continued in the form of a decline in unemployment. The unemployment rate fell by 1.6 percentage points year on year to $6.1 \%$ in the fourth quarter of 2018. It was the lowest measured value since the start of the survey performed by The Statistical Office of the Slovak Republic, reaching its historical minimum. Furthermore, the unemployment rate for 2018 averaged $6.5 \%$ (8.1\% for 2017) according to OECD data (2019). The abovementioned facts are presented below in Figure 3.

Figure 3: Number of unemployed and the unemployment rate

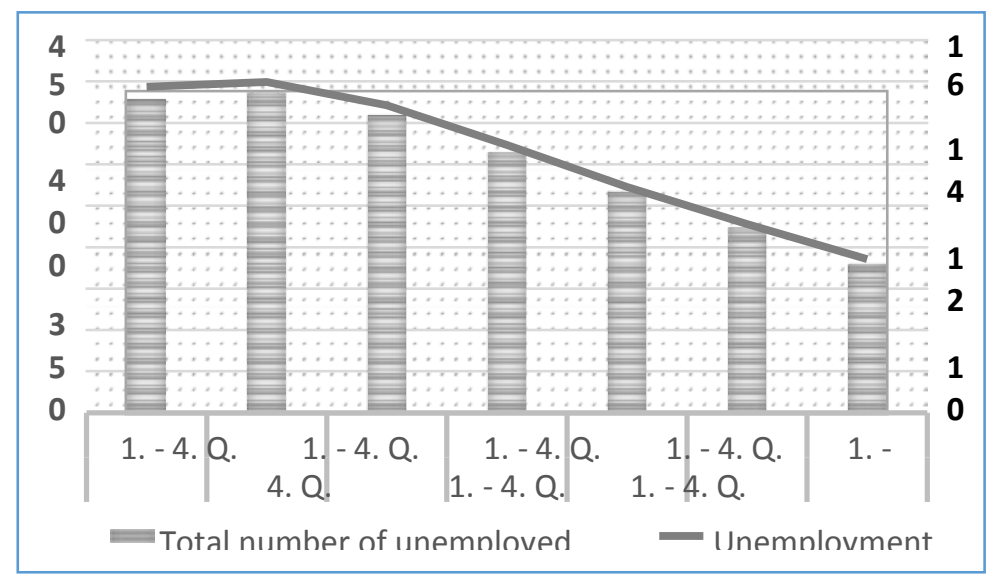

Source: Authors' representation of the data provided by the Statistical Office of the Slovak Republic (2019) 
The situation on the labor market was positively influenced by the achieved economic growth. According to the SO SR quarterly reporting, the average number of employed individuals increased by 43.9 thousand in 2018 compared to the previous year. Given the negative demographic development and the decreasing number of unemployed individuals, employment growth slightly slowed down in 2018. Based on the Statistical Office of The Slovak Republic findings (2019), the average registered number of employees in organizations with $20+$ employees increased by $1.8 \%$ year-on-year. Employment growth was registered in all regions except Košice. The highest degree of employment growth was registered in the Prešov region and the Bratislava region still dominates the labor market with a share of $33.4 \%$ of the total number of employees (for organizations with 20 or more employees).

Within individual sectoral statistics, the average year-on-year increase in employment was recorded in 2018, especially in information and communication activities (by 6.9\%), transport, storage, sales and repair of motor vehicles (both by 6.4\%), selected market services (by 6.2\%), in restaurant and catering activities (by 5.9\%), accommodation (by 5.7\%), construction and retail trade (both by 3.3\%), and in industrial production (by 3\%). Recording the highest increase in employment in information and communication activities can now be viewed as a positive phenomenon in the labor market (Statistical Office of the Slovak Republic, 2019).

In 2018, the number of job vacancies increased by an average of 3965 (by 18.8\%) year-on-year to 25088 jobs, causing problems for employers to fill vacancies with suitable candidates. Employment growth is also slowing down due to problems with the employment of suitable workforce. A specific phenomenon accompanying labor market developments is also the influx of foreign workers or the decreasing number of Slovaks working abroad.

In connection with the increasing employment rate, the number of Slovaks working abroad was also declining in 2018. The sectors where the Slovak population found employment were mainly construction, industry, health care and the social sphere. Of all European countries, 
Slovak citizens mostly worked in Austria and the Czech Republic. Work abroad was mainly found in the Prešov, Žilina and Nitra regions. The Slovak Republic is a country that faces the outflow of qualified workers abroad, and the country's index of aging is one of the most dynamic in Europe (Grenčiková et al., 2018). Figure 4 provides an overview of shortterm migration abroad measured in thousands of individuals.

Figure 4: Development of short-term migration abroad (in thousands of individuals)

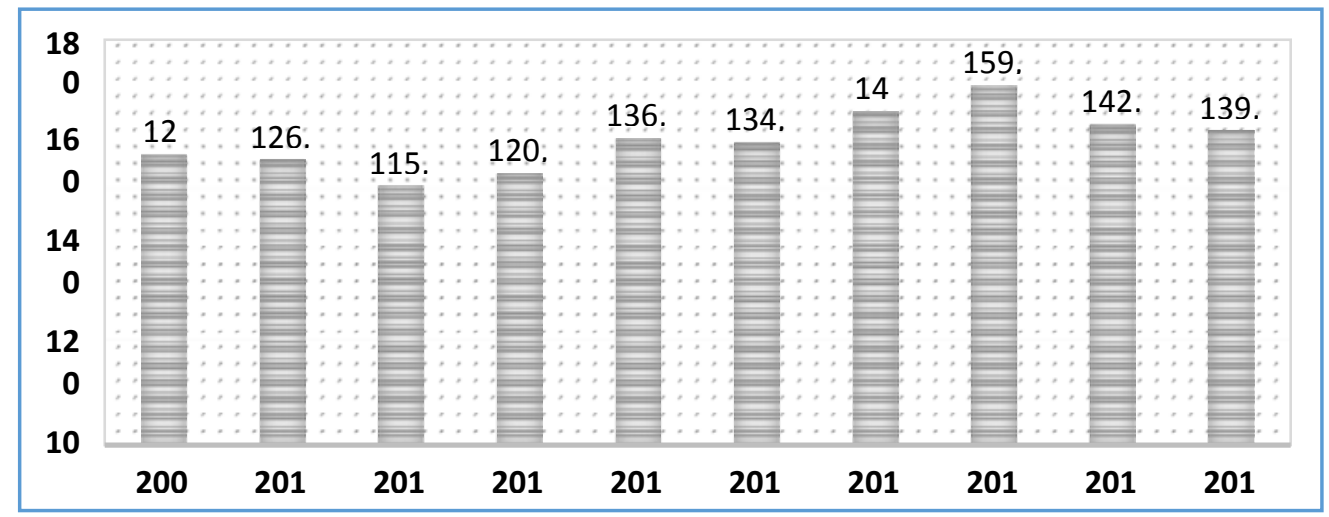

Source: Statistical Office of the Slovak Republic (2019)

Not only are citizens of Slovakia leaving for work abroad, but also thirdcountry nationals are coming to work in Slovakia (Figure 4). The lack of a skilled labor force on the domestic market is therefore addressed by employers by employing foreigners. At the end of 2018, the total number of third-country nationals carrying out work activities in the Slovak Republic was 32,851. Citizens of Serbia, Ukraine and Bosnia and Herzegovina have the highest representation, judging by the data from the Central Office of Labor, Social Affairs and Family (ÚPSVR), from thirdworld countries. The development of employment rate regarding foreigners from third-world countries in Slovak Republic are presented in Figure 5. 
Figure 5: Employment rate of foreigners from third world countries in the Slovak Republic

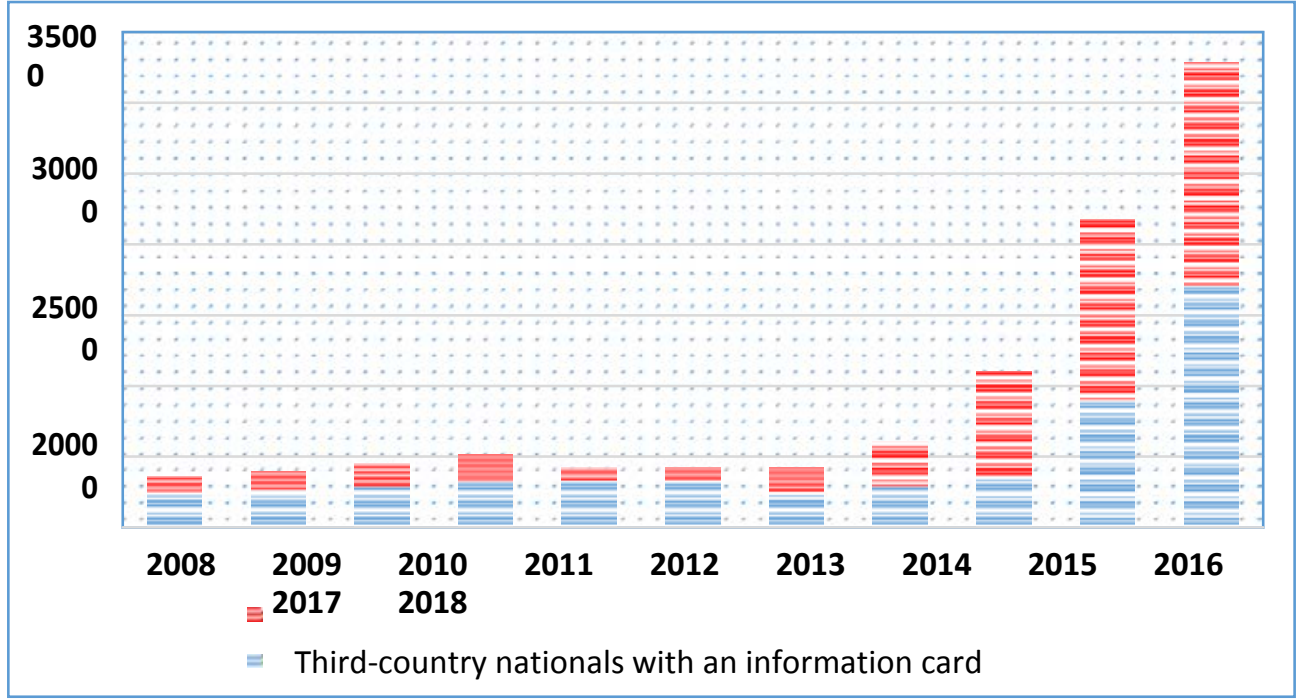

Source: Central Office of Labor, Social Affairs and Family in Slovak Republic (2019)

According to Špirková (2018), the harmony between housing (the real estate market) and working opportunities (the labour market) became an essential part of public policy of the state and self-government in Slovak Republic.

\section{WAGES AND LABOR COSTS}

In 2018, the average nominal monthly wage of an employee in the economy was EUR 1,013. It increased year-on-year by $6.2 \%$ and the real wage increased by $3.6 \%$. For the period 2008 to 2017 , the average wage increased by $€ 231$ and the minimum wage increased by $€ 166.83$, which in 2017 was the largest increase in the minimum wage in Slovakia's history. The illustrative movements in minimum and average wage are presented on Figure 6. 
Figure 6: Development of minimum wage and average wage (in EUR)

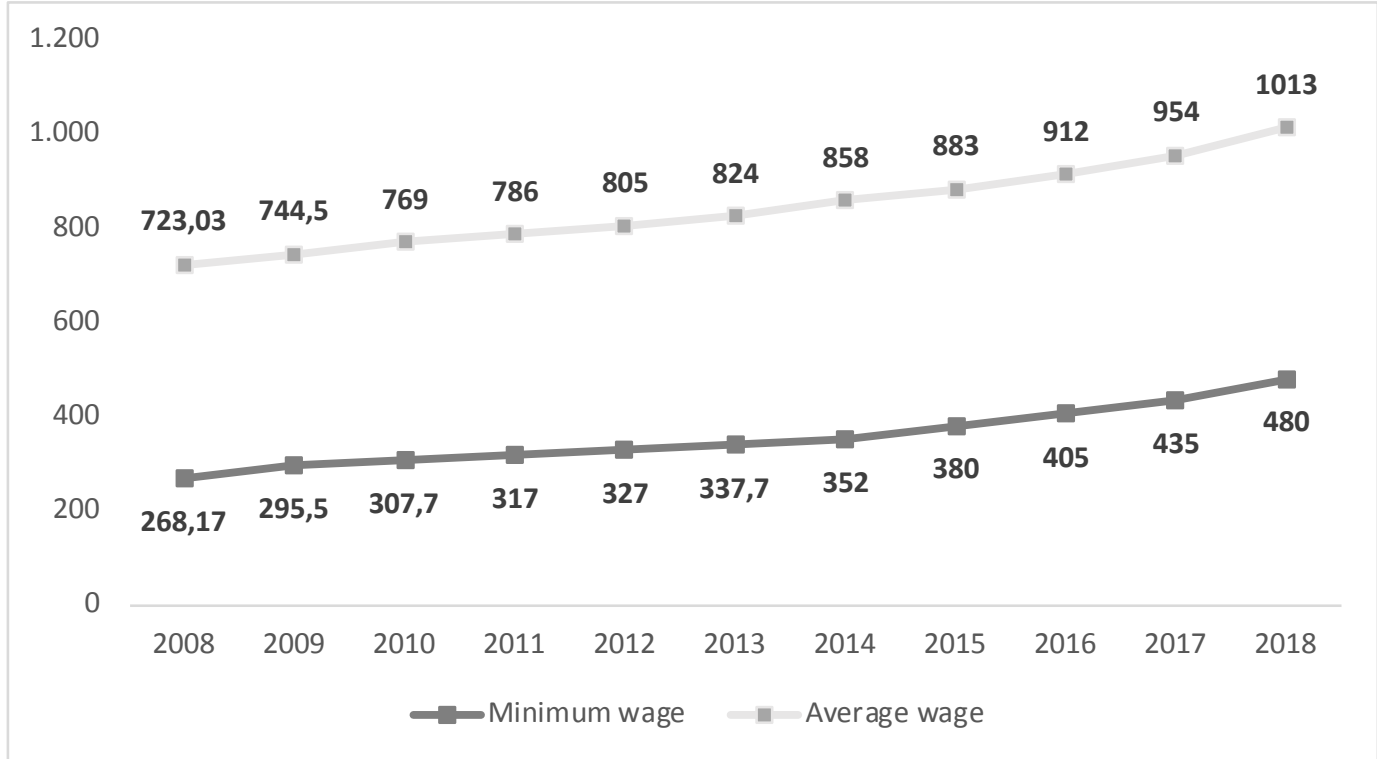

Source: Statistical Office of the Slovak Republic; Eurostat (2019)

\section{INFLATION AND THE DEVELOPMENT OF INFLATION}

Figure 7: Slovakia: Inflation rate from 2014 to 2022 (compared to the previous year)

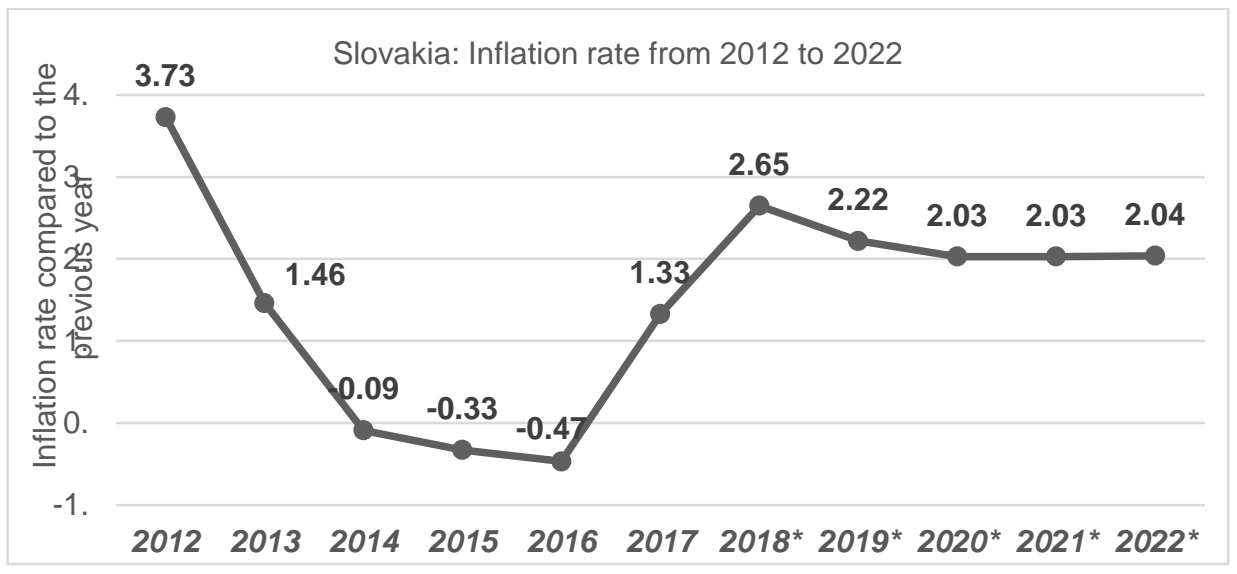

Source: Statista - The Statistics Portal (2019) 
This statistical data in Figure 7 show the average inflation rate in Slovakia from 2014 to 2018, with projections up until 2024. In 2018, the average inflation rate in Slovakia increased about 2.53 percent compared to the previous year. From the economic point of view, Slovakia is doing well, but it lags in key areas for future growth, which is stated by the European Commission (EC) in the Report on Slovakia 2019. Also, the mentioned report highlighted the major developments in Slovak Republic in previous periods marking high economic growth or low unemployment as priorities.

Figure 8: Annual business confidence index for the industrial sector in Slovakia 2008-2022

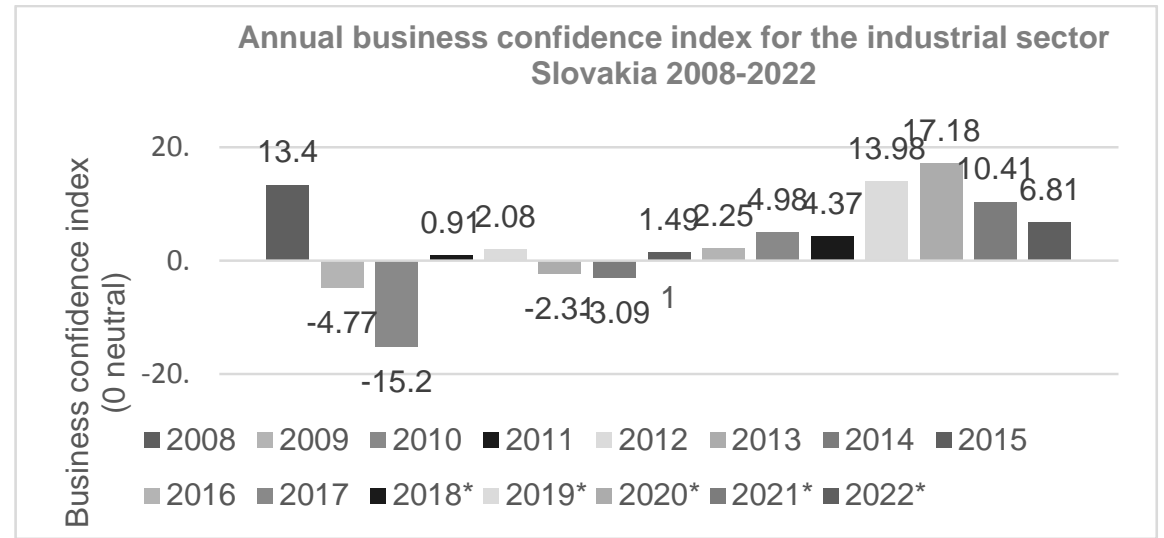

Source: Statista - The Statistics Portal (2019)

These data show the business confidence index for the industrial sector in Slovakia from 2008 to 2017, with projections up until 2022. In 2017, the confidence index for the Slovakian industry ranged at approximately 4.98 index points, indicating an increase in business confidence.

\section{FOREIGN TRADE}

Economy of the Slovak Republic could be described as a very open economy. A significant part of total exports (85\%) goes to EU countries. Exports are dominated by the automotive, electrical, metallurgy, petrochemical and chemical industries. The imports are dominated by the electronics, automotive, energy and pharmaceutical industries. 
Exports of the Slovak Republic in 2018 amounted to 79.786 billion EUR and increased by $6.7 \%$ year-on-year. Imports reported a value of 77.326 billion EUR and increased by $7.8 \%$ year-on-year. The foreign trade balance was positive in the amount of 2.46 billion CZK (Businessinfo, 2019). Over the past three years, the trade surplus has been gradually decreasing.

Among the most important trading partners in 2018, Slovak exports increased year-on-year as follows: Germany $(+15.3 \%)$, Czech Republic $(+9.8 \%)$, Poland $(+5.8 \%)$, France $(+6.7 \%)$, Italy $(+2.2 \%)$, Austria $(+1.6 \%)$, USA (+25.3\%), Spain $(+2.2 \%)$, Romania $(+9.9 \%)$ and Russia $(+0$, $9 \%)$. On the other hand, exports to Hungary $(-1.8 \%)$, the United Kingdom (-6.9\%) and the Netherlands (-8.0\%) declined (Businessinfo, 2019). Among the most important trading partners in 2018, Slovak imports increased year-on-year as follows: Germany $(+13.7 \%)$, Czech Republic $(+5.5 \%)$, Vietnam $(+16.3 \%)$, South Korea $(+9.1 \%)$, Poland $(+10.4 \%)$, Russia $(+21.5 \%)$, Hungary $(+5.2 \%)$, Italy $(+9.0 \%)$, France $(+3.2 \%)$, Austria $(+8,8 \%)$. On the other hand, imports from China decreased yearon-year (-15.1\%) (Businessinfo, 2019).

Slovak Republic posted the highest trade balance in 2018 with the following countries: Germany ( +4.023 billion EUR), the United Kingdom $(+2.676$ billion EUR), France $(+2.673$ billion EUR), Austria ( +2.192 billion EUR) Italy $(+1.971$ billion EUR), the USA $(+1.898$ billion EUR), Poland $(+1.810$ billion EUR), the Czech Republic $(+1.539$ billion EUR), Spain (+1.080 billion EUR) and Romania (+887 million EUR). The largest trade deficit in 2018, as reported by Slovakia, was with the following countries: Vietnam (-4.459 billion EUR), South Korea (-4.339 billion EUR), China (3.144 billion EUR), Russia (-2.549 billion EUR) Malaysia (-478 million EUR), Taiwan (-413 million EUR), Japan (-337 million EUR), Ukraine (201 million EUR), India (-199 million EUR) and Turkey (-109 million EUR) (Businessinfo, 2019). 


\section{INVESTMENT - FOREIGN DIRECT INVESTMENT IN THE TERRITORY (SECTORAL AND TERRITORIAL STRUCTURE)}

New investment means an increase in new wages, which was positively reflected in the fall in unemployment. In particular, new investment also means modernizing production (Smolen \& Komornik, 2019), which has resulted in increased imports into the country, but new technologies have led to higher labor productivity. Increased labor productivity is followed by an increased export of manufactured goods and services abroad.

At the end of 2018, Foreign direct investment (FDI) in the Slovak Republic reached the value of 46.6 billion Euro. FDI was directed primarily to manufacturing (36\%), finance and insurance (25\%), wholesale and retail (9\%), real estate (7\%), administrative and support services (7\%), information and communication technologies (6\%). The energy sector of Slovakia has also benefited greatly from foreign direct investments (Smolen, 2013).

Within production, FDI are primarily directed towards the following sectors (Trading Economics, 2019):

- engineering and automotive (Volkswagen, PSA Peugeot Citroen, Kia Motors, Jaguar Land Rover)

- electrical industry (Samsung, Foxconn, Whirlpool)

- petrochemical and chemical industry (MOL Group, Continental, Agrofert Holding, BASF)

- metallurgy (US Steel, ArcelorMittal, Nemak)

- energy (energy and industrial Holding, Enel, E.ON)

- food and beverages (Heineken, Nestlé, Meggle).

Foreign direct investments in Slovak Republic are coming from various countries, that are presented in Table 1. 
Table 1: Overview of foreign direct investments in the Slovak Republic per countries

\begin{tabular}{|c|c|c|}
\hline Country & Euro & Company \\
\hline Austria & 6.08 billion & $\begin{array}{l}\text { Erste Group, Glock, MIBA, Michatek, } \\
\text { OMV, ZKW }\end{array}$ \\
\hline Czech Republic & 5 billion & $\begin{array}{l}\text { Agrofert, PPF, Plzensky Prazdroj, Hamé, } \\
\text { Czech arsenal, Czechoslovak Group, Charvát } \\
\text { Group, TTS Trebic, CEZ Esco }\end{array}$ \\
\hline Luxembourg & 3.43 billion & ArcelorMittal Gonvarri SSC \\
\hline Germany & 2.97 & $\begin{array}{l}\text { Volkswagen, Continental, Hella, Osram, } \\
\text { Siemens, Deutsche Telecom, T-Systems, } \\
\text { Vaillant }\end{array}$ \\
\hline South Korea & 2.95 & $\begin{array}{l}\text { Kia Motors, Hyundai Dymos, Mobis, } \\
\text { Samsung Electronics, Yura, Hanon Systems }\end{array}$ \\
\hline Hungary & 2.65 & MOL Group \\
\hline Belgium & 2.42 & $\begin{array}{llll}\text { Aspel, } & \text { Bekaert, } & \text { Carmeuse, } & \text { Deltrian, } \\
\text { Fremach, Plastiflex } & & \end{array}$ \\
\hline Italy & 2.19 & Enel, Magneti Marelli, Mevis, Lombardini \\
\hline United Kingdom & 1.09 & 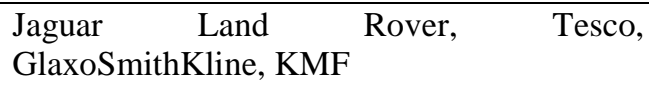 \\
\hline Sweden & 915 mil. & Ericsson, IKEA, Lindab, Dometic \\
\hline France & 914 mil. & $\begin{array}{l}\text { PSA Peugeot Citroen, Alcatel-Lucent, } \\
\text { Orange, Treves }\end{array}$ \\
\hline Spain & 726 mil. & $\begin{array}{l}\text { Nemak, Grupo Antolin, CIKAUTXO, } \\
\text { Cortizo, Fagor }\end{array}$ \\
\hline Switzerland & 619 miles. & $\begin{array}{l}\text { ABB, Enics, Lafarge, Holcim, Nestlé, Nexis, } \\
\text { Novartis, Schindler, Swiss Re }\end{array}$ \\
\hline USA & 300 mil. & $\begin{array}{l}\text { US Steel, Whirlpool, Johnson Controls, } \\
\text { IBM, Honeywell, Lear Corporation, } \\
\text { Accenture, Amazon }\end{array}$ \\
\hline Japan & 105 mil. & $\begin{array}{l}\text { Minebea, Asahi, } \\
\text { Akebono, U-Shin }\end{array}$ \\
\hline
\end{tabular}

Source: Trading Economics (2019) 


\section{CONCLUSION}

Thanks to the reforms that had already been carried out, Slovakia has a good economic situation, but it is necessary to conduct a sound economic policy to reduce debt and improve the business environment. In order to be competitive in the global competitive environment, Slovak economy must significantly influence the advent of the fourth industrial revolution, which brings with it several challenges, especially in connection with the advent of automatization, digitalization and process optimization.

In terms of its competences, Slovakia constantly improves the business environment and the development of innovations, but must identify the current shortage of skilled labor as one of the most serious challenges for Slovakia's economic development. Future digitization fundamentally changes the nature of industry and has significant impacts on other parts of the economy and society. We can consider innovation as one of the key areas for the economic growth and competitiveness of businesses, regions and, consequently, the economy of the state as such, whilst The Slovak Republic is lagging long term in terms of innovation performance.

\section{REFERENCES}

1. Businessinfo (2019). Retrieved April 27, 2019, from: https://www.businessinfo.cz/cs/zahranicni-obchod-eu/teritorialniinformace-zeme/slovensko.html

2. Central Office of Labor, Social Affairs and Family in Slovak Republic (2019). Retrieved April 27, 2019, from: https://www.upsvr.gov.sk/volne-pracovnemiesta.html?page_id=12925\&lang=en

3. Eurostat (2019). Retrieved April 27, 2019, from: https://ec.europa.eu/eurostat

4. Grenčiková, A., Skačkauskienè, I. \& Španková, J. (2018). The features of labor emigration from the Slovak Republic. Verslas teorija ir praktika 19(2):271-277. DOI: $10.3846 /$ btp.2018.27

5. OECD (2019). Retrieved April 27, 2019, from: https://data.oecd.org/slovak-republic.htm

6. Smolen, J. (2013). Revenue management in electricity sector. International Journal of Arts and Sciences. Vol. 6, No. 1, p. 519-532 
7. Smolen, J. (2016). Supply, demand and price development on the German electricity market during the last 10 years period. Management in theory and practice, p. $120-125$

8. Smolen, J. \& Komornik, J. (2019). Financny manazment, Univerzita Komenskeho, Bratislava

9. Statista - The Statistics Portal (2019). Retrieved April 27, 2019, from: https://www.statista.com/statistics/375270/gross-domestic-productgdp-growth-rate-in-slovakia/

10. Statista - The Statistics Portal (2019). Retrieved April 27, 2019, from https://www.statista.com/statistics/375275/inflation-rate-in-slovakia/.

11. Statistical Office of the Slovak Republic (2019). Retrieved April 27, 2019,

12. Statista - The Statistics Portal (2019). Retrieved April 27, 2019, from https://www.statista.com/statistics/370764/slovakia-industrial-sectorbusiness-confidence-index/

13. Trading Economics (2019). Retrieved April 27, 2019, from https://tradingeconomics.com/slovakia/foreign-direct-investment

14. World Bank (2019). Retrieved April 27, 2019, from: https://data.worldbank.org/indicator/NY.GDP.MKTP.KD.ZG?view=chart

15. Špirková, D. (2018). Housing Policy in the Slovak Republic. DOI: 10.5772/intechopen.78611, November 2018.

\title{
EKONOMSKI RAZVOJ U REPUBLICI SLOVAČKOJ: OSTVARENI REZULTATI I PERSPEKTIVE BUDUĆEG RAZVOJA
}

\author{
Dudić Branislav \\ Beňová Eleonóra \\ Mirković Vladimir \\ Dudić Zdenka
}

Sažetak: Proces pristupanja Slovačke Evropskoj uniji je dao pozitivan impuls daljem ekonomskom razvoju u kontekstu kretanja osnovnih indikatora poslovnog okruženja, a na osnovu analize opšteg makroekonomskog ambijenta, BDP-a i tržišta radne snage. Slovačka 
se orijentiše na aktuelne trendove koji se pre svega odnose na nedostatak obučene radne snage i zapošljavanje stranih državljana. Najznačajniji zadatak Vlade Republike Slovačke jeste obezbeđivanje održivog ekonomskog razvoja, zajedno sa otvaranjem novih radnih mesta i poboljšanjem uslova poslovanja. Strane direktne investicije i sektor privrede treba da budu nosioci budućeg razvoja ekonomije i zaposlenosti u Slovackkoj. Nove investicije podrazumevaju modernizaciju proizvodnje, nove tehnologije, otvaranje novih radnih mesta $i$ napredak ekonomije. $U$ radu se posebno ističe doprinos četvrte industrijske revolucije, oličen $u$ vidu automatizacije $i$ digitalizacije procesa i kontinuiranim inovacijama, ekonomskom rastu i razvoju Slovačke.

Ključne reči: ekonomski rast / poslovno okruženje / BDP / investicije / zaposlenost / Slovačka 